\title{
TREE RINGS FOR THE ASSESSMENT OF THE POTENTIAL IMPACT OF CLIMATE CHANGE ON FOREST GROWTH
}

\author{
SHAH, S. ${ }^{1} *-\mathrm{SHAH}, \mathrm{C}^{2}$ \\ ${ }^{I}$ Dr. Y.S. Parmar University of Horticulture and Forestry, Solan, Himachal Pradesh - 173230 \\ (phone: +91-8-447-640-621) \\ ${ }^{2}$ World Class Skilll Centre, Vivek Vihar, Delhi-110095 \\ (phone: +91-9-711-157-328, e-mail: chetan_shah@rocketmail.com) \\ *Corresponding author \\ e-mail:drshiprashah1984@gmail.com \\ (Received 22 ${ }^{\text {nd }}$ May 2014; accepted $14^{\text {th }}$ Aug 2014)
}

\begin{abstract}
The Earth's climate is changing rapidly and while human influence on the same is an inconvenient truth, it is important to assess the likely impacts of climate change on vulnerable ecosystems across the globe. Forests contain the world's largest terrestrial carbon pool and constitute a major sink that reduces the build-up of atmospheric carbon dioxide. Climate change is likely to result in substantial changes in the structure and function of forests. The effects of climate variability on forests can be best estimated from tree rings which are highly sensitive to changes in environmental conditions. However, there is conflicting evidence as regards the response of forests to climate change. Will climate change accelerate tree growth and mitigate $\mathrm{CO} 2$ release from fossil fuels and land-use change? Or would the outbreak of forest fires, insect attacks and storms negate any increase in forest carbon storage from faster growth, the 'divergence problem', as propounded by some researchers? Climatic variations in recent decades and in the years to come may pose grave threats to the world's forests and their role as potential carbon sinks, hence concerted research is needed in the future to validate the claims of forest growth dynamics in relation to climate change.
\end{abstract}

Keywords: climate, forests, tree rings, growth, carbon

\section{Introduction}

The earth's climate is a complicated, multi-component system which has experienced many changes and variations throughout its history. The 20th Century was a pivotal period as it marked the onset of a rapid climatic warming brought on by major anthropogenic changes in global atmospheric composition. Climate change has been one of the most engaging environmental subjects of debate in recent times. Intergovernmental Panel on Climate Change (IPCC, 2007) states that "Climate change is a change in the state of the climate that can be identified by changes in the mean and / or the variability of its properties and that persists for an extended period typically decades or longer". Nigeria's First National Communication on climate change under United Nations Framework Convention on Climate Change (UNFCCC) defines climate change as a change of climate which is attributed directly or indirectly to human activities that alter the composition of the global atmosphere and which are in addition to natural climate variability, observed over comparable time period.

The fourth assessment report of the IPCC specifies the linear trend of global mean surface temperatures over the last century - from 1906 to 2005 - with $0.74^{\circ} \mathrm{C} \pm 0.18^{\circ} \mathrm{C}$. Climate warming is by now unequivocal, as it is evident from observations of increases in global average air and ocean temperatures, widespread melting of snow and ice, and rising global average sea level (IPCC, 2007).

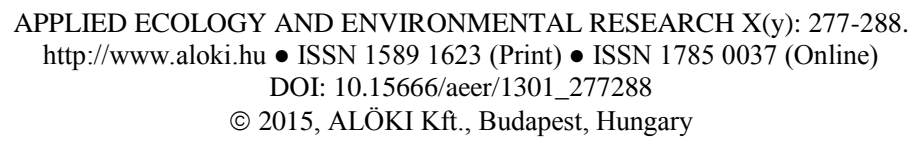


Forests are particularly sensitive to climate change, because the long life-span of trees does not allow for rapid adaptation to environmental changes. Unlike in agriculture, adaptation measures for forestry need to be planned well in advance of expected changes in growing conditions because the forests regenerated today will have to cope with the future climate conditions of at least several decades, often even more than 100 years. Thus it is important to understand the response of unmanaged natural forests to changing climate because it is possible to adapt forest management practices to a changing environment (Lopatin et al., 2008).

Dendrochronology (the study of tree rings) provides important information for reconstructing past climate and assessing the impacts of climate change and disturbance events on tree growth (Abrams and Orwig, 1995; Mann et al., 1999; Abrams, 2003). Tree rings, when viewed as time series of annual increments, present a valuable, longterm record of tree growth across many forest environments. Tree species are unique in their response to environmental conditions and can be used as a fingerprint of recent climate change (Root et al., 2003) and a natural archive of past climate (Fritts, 1976).

The impact of climate change on the world's forests is a debatable issue. There is uncertainty as to whether the rising temperatures and the changing precipitation patterns may enhance or decline the growth and productivity of forests. Different workers have different inferences concerning this question. Large-scale greening in some northern regions observed in satellite data since the early 1980s (Myneni et al., 1997; Nemani et al., 2003; Brown et al., 2004) is thought to be due to enhanced warming; however in some areas it could be replaced by decreased growth, browning (Bunn and Goetz, 2006) and weakened sensitivity of temperature response in trees (D'Arrigo et al., 2004a). Evidence of improving vegetation productivity in the coastal Arctic tundra initiated by climatic warming during the late 20th to early 21 st Centuries are cumulating in analyses of satellite data and in situ field measurements. In contrast, areas of declining vegetation productivity were documented in the southern adjacent boreal ecosystems across a belt stretching from Interior Alaska to northwestern Quebec (Girardin, 2014). Herein we provide an overview of key studies on the impact of climatic changes on the growth of forests as estimated through tree ring analysis.

\section{Tree rings as natural archives of climate}

Climatic changes have been recorded by different natural systems such as pollen records, ice cores, corals, caves, varves and tree-rings which can be utilized as archival records of past climates (Bradley, 1992). The use of tree-ring series has also recently spread to climate model validation in the context of global warming assessment. The most important premises for applying the tree-ring studies to forest dynamics are to find out the existence of critically good and bad years for tree growth, to define them objectively and quantitatively and to find out the common factors that are responsible for the growth fluctuation.

Dendrochronology is the science of tree-ring dating. Andrew E. Douglass is considered the founder of the discipline of Dendrochronology. According to Fritts, 1987, the term dendro is from dendron, the Greek word for tree, and chronology means the assignment of dates to particular events in a time series. The study of past and present climate from tree rings is known as dendroclimatology (Fritts, 1976). The fundamental scientific basis of dendrochronology, established by Douglass in the early 20 th century, is that climate affects all trees in a given area consistently. This means that

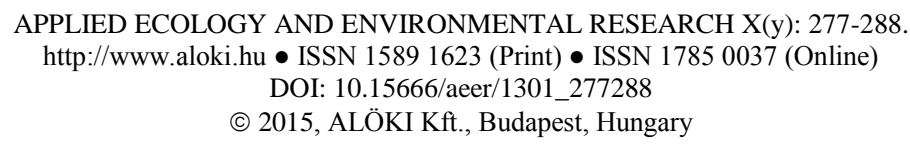


the pattern of relative ring width variation between different trees from close locations should be very similar for a given time period, even though their absolute ring widths may be quite different. This could be, for example, due to local soil conditions at a particular tree. Dendrochronology works on the principle that over a long period of time (especially 100 years or more) there is a pattern of tree-rings of wider and narrower rings which respectively reflect years favourable for the tree versus bad years and that the period during which any tree lived will be uniquely represented in its tree-ring pattern (considering all features, including ring-widths).

Matching of relatively fast and slow growth ring patterns among trees is called crossdating (Swetnam et al., 1985). By coupling this to climate data, it is possible to establish a connection between critical climatic variables and tree growth. When tree rings are dated to the exact calendar year through the technique of crossdating (Stokes and Smiley, 1968), the science of dendroclimatology extracts the maximum amount of climatic information contained in the tree-ring record.

The major strengths of tree rings as climate change indicators are (i) their annual resolution, (ii) the existence of large geographic-scale patterns of synchronic interannual variability, (iii) the increasing availability of extensive networks of tree-ring chronologies, and (iv) the possibility of using simple linear models of climate-growth relationships that can be easily verified and calibrated (Hughes, 2002). Their weaknesses include (i) an intrinsic sampling bias, given that tree-ring information is available only for terrestrial regions of the globe, (ii) the fact that methods used to extract growth signals from tree-ring series retain only certain wavelengths of climate variability (IPCC, 2001) (iii) the complexity of biological responses to climate forcing, and (iv) the presence of nonclimatic variability in the series attributable to intrinsic growth trends and other nonclimatic disturbances (Fritts, 1976).

\section{Anticipated impacts of climate change on forest growth}

Rising atmospheric $\mathrm{CO} 2$ concentration, higher temperatures, changes in precipitation, flooding, drought duration and frequency will have significant effects on tree growth. Changes in species dominance, species distribution, species survival, fecundity and phenological phases are likely to occur. Tree-line fluctuations and species migration are another major anticipated impact. Rowe (1967) reported a northward migration rate of $150 \mathrm{~m}$ per year for the boreal forests in Canada and Bruce and Hengeveld (1985), suggested that tree lines in Canada would gradually migrate $100 \mathrm{~km}$ northward for every Celcius degree of warming.

Among these possible impacts, the impact of elevated $\mathrm{CO} 2$ on tree physiology and growth has been the subject of an enormous amount of scientific investigation over the last 50 years (Bazzaz, 1990). The lengthening of the growing season due to changes in the temperature and precipitation regime coupled with increasing $\mathrm{CO}_{2}$ and nitrogen deposition are assumed to cause increased forest growth (Makinen et al., 2003). Recent studies suggest that the turnover and growth rates of tropical forests have increased in the last few decades due to stimulation of forest growth caused by increase in $\mathrm{CO}_{2}$ concentrations in the atmosphere (Baker, 2004; Lewis, 2006; Phillips, 2009). Many $\mathrm{CO} 2$ enrichment experiments, conducted at the plant or stand scale, have consistently reported positive effects of elevated CO2 on tree growth (Tissue et al., 1997; Telewski et al., 1999). However, it is suggested that forest trees may now be CO2 saturated and further increases in atmospheric $\mathrm{CO} 2$ will not lead to further enhancements in

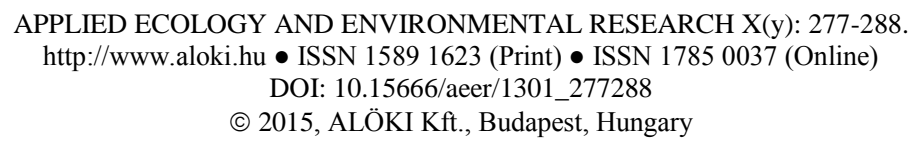


photosynthesis and growth (Korner, 2003). On the contrary, a decline in forest growth and productivity with the changing climate is anticipated. As opposed to the enhancement effect of elevated $\mathrm{CO} 2$, the increase in tropospheric ozone in many parts of the world typically has detrimental impacts on trees (Karnosky et al., 2007). These negative impacts on tree physiology and growth typically counteract the positive impacts of elevated $\mathrm{CO} 2$ although the impacts of ozone are much more localized than those of elevated $\mathrm{CO} 2$. Recent results from an outdoor field experiment in the northern U.S. showed that the expected benefits of elevated $\mathrm{CO}_{2}$ on aspen growth were negated when ground-level ozone was raised to the levels occurring in more polluted areas (Isebrands et al., 2001). Besides, predicted temperature increases in arid environments may exacerbate the effects of water stress even if soil water availability is not directly affected. While small increases in temperature often result in increased photosynthesis and tree growth (Way and Oren, 2010), large increases in temperature are inhibitory.

An anomalous reduction in forest growth indices and temperature sensitivity has been detected in tree-ring width and density records from many circumpolar northern latitude sites since around the middle 20th century. This phenomenon is known as the 'divergence problem'. The possible causes include temperature-induced drought stress, nonlinear thresholds or time-dependent responses to recent warming, delayed snowmelt and related changes in seasonality, and differential growth/climate relationships inferred for maximum, minimum and mean temperatures. Another possible cause of the divergence is 'global dimming', a phenomenon that has appeared, in recent decades, to decrease the amount of solar radiation available for photosynthesis and plant growth on a large scale (D'Arrigo et al., 2008).

\section{Tree ring studies supporting enhanced forest growth in response to climate change}

Several studies have been conducted to study the impact of climate change on forest growth through tree ring analysis. Climatic warming may be expected to benefit the productivity of forests, especially in cold climatic regions where the length of the growing season is limited by low temperatures. Further benefits may be expected owing to the role of $\mathrm{CO}_{2}$ in the photosynthesis of trees and other plants: as $\mathrm{CO}_{2}$ levels increase, forest growth will tend to increase due to $\mathrm{CO}_{2}$ fertilization effect, if other factors are not limiting. It has also been suggested that large-scale forest productivity has been significantly enhanced by human-induced increases in nitrogen $(\mathrm{N})$ deposition (Chen et al., 2000). The inclusion of these positive effects in global models has led to projections of increasing forest productivity and carbon sequestration over the next century, especially in northern forests (Cao and Woodward, 1998; White et al., 1999). In a survey of 11 leading ecologists, most believed that standing biomass of northern forests is likely to increase under future climate change with a doubling of $\mathrm{CO}_{2}$ levels, although soil carbon was generally expected to decrease (Morgan et al., 2001). A recent global analysis of remote sensing measurements from 1981 to 1999 suggests that the recent warming trend has led to an overall greening of most northern areas, especially in Eurasia (Zhou et al., 2001).

Increasing ring widths in recent decades in subalpine pines in New Mexico, Colorado and California (LaMarche et al., 1984) in Pinus uncinata at the tree line in the Pyrenees (Badeau et al., 1996) and in subalpine Pinus cembra in the central Alps (Nicolussi et al., 1995) have been cited as evidence of possible $\mathrm{CO} 2$ enhanced growth. Finally, strong evidence for $\mathrm{CO} 2$ growth enhancement comes from tree ring analyses of Quercus ilex

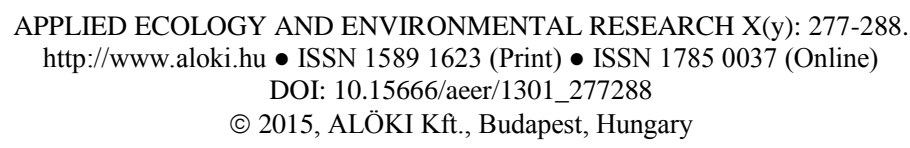


continuously exposed to about $650 \mathrm{ppm} \mathrm{CO} 2$ near natural $\mathrm{CO} 2$ vents in Italy. These trees have grown about $12 \%$ faster than those growing in ambient $\mathrm{CO} 2$ nearby, especially when the trees were young and during dry seasons (Hattenschwiler et al., 1997). Across northern latitudes, ring width analyses suggest that forests started growing faster after 1850, well before the warming that occurred in the first half of the 20th century, but when CO2 levels first started to increase (Briffa et al., 1998b). Another intriguing observation is that the NPP (as measured by rates of tree mortality and recruitment - the turnover rates) of humid tropical forests throughout the world seem to have increased in recent decades (Phillips and Gentry, 1994).

One study in central Nevada found that the widths of annual rings of bristlecone (Pinus longaeva) and limber pine (Pinus flexilis) trees near timberline were 106 percent greater in the decade ending in 1983 than in the years 1850 to 1859 at one site and 73 percent greater at another. They explained that the observed increase in tree-ring widths was due to an increase in biomass due to elevated $\mathrm{CO} 2$. The $\mathrm{CO} 2$ fertilization hypothesis proposes that plants will grow faster under elevated atmospheric $\mathrm{CO} 2$ concentrations; that accelerated growth might take many forms like increase in underground root mass, increase in foliage and increase in cambial activity and thus tree-ring width (LaMarche et al., 1984).

In the mixed-grass prairie of southwestern Manitoba, Canada the evidence of an atmospheric $\mathrm{CO} 2$ fertilization effect on radial growth rates for open-grown white spruce was found. About $61 \%$ of the total variation in radial growth index was explained by climate for both young and old trees, residuals from young trees for the period of 1955-1999 demonstrated a stronger upward trend than old trees for the period of 1900-1996. The results suggested that (1) open-grown white spruce trees improved their growth with time at the early developmental stage, and (2) at the same developmental stage, a greater growth response occurred in the late period when atmospheric $\mathrm{CO} 2$ concentration, and the rate of atmospheric $\mathrm{CO} 2$ increase were both relatively high (Wang et al., 2006).

The tree-ring records of Siberian larch in the Egiin Davaa region in Hangay mountains, Mongolia, reaching altitudes in excess of $3500 \mathrm{~m}$ showed sustained overall increase in growth despite aging of the trees, suggesting that growth conditions were considerably more favorable in the 20th Century (Stratton, 2007).

In Komi Republic of northwestern Russia both Siberian spruce (Picea obovata) and Scots pine (Pinus sylvestris) showed increased radial growth in response to increasing temperature and precipitation in the region. Thus, climate change could partly explain the increased site productivity (Lopatin et al., 2008).

Another study found that the Great Basin bristlecone pine (Pinus longaeva) in western North America near the upper elevation limit of tree growth showed ring growth in the second half of the 20th century that was greater than during any other 50year period in the last 3,700 years. The accelerated growth is suggestive of an environmental change unprecedented in the millennia. Both an independent proxy record of temperature and high-elevation meteorological temperature data were positively and significantly correlated with the ring width both before and during the high-growth interval. The study concluded that increasing temperature at high elevations is likely a prominent factor in the modern unprecedented level of growth for Pinus longaeva at these sites (Salzer et al., 2009).

Analysis of instrumental period surface air temperature data over the region indicated significant increasing trend over the last century with a noticeable warming during the 
recent four decades. A study of Himalayan conifers (Cedrus deodara, Picea smithiana) observed an anomalous higher growth during the last few decades in the multi century tree-ring width chronologies near the glacier areas of Kinnor and Gangotri in Western Himalayas. These chronologies indicated strong relationship to the mean annual and winter temperatures of concurrent year (Borgaonkar et al., 2009).

Increasing growth in European forests was also found by Laubhann et al. (2009) who studied the effects of climate change on four species namely common beech (Fagus sylvatica), oak (Quercus petraea and Q. robur), Scots pine (Pinus sylvestris) and Norway spruce (Picea abies) in 382 plots in 18 European countries. Increasing temperature showed a positive effect on growth for all species except Norway spruce. Nitrogen deposition showed a positive impact on growth for all four species.

\section{Tree ring studies supporting reduced forest growth in response to climate change}

Contradictory results have also been recorded by several researchers who negate the phenomenon of enhanced forest growth particularly in the northern hemisphere due to climate change. The divergence problem in dendroclimatological studies as mentioned earlier has two premises, one that it is more pronounced in the northern latitudes and two that it may be anthropogenic in origin. A recent analysis by Cook et al. (2004a) suggests that the divergence is restricted to the recent period and is unique over the past thousand years. It is thus likely to be anthropogenic in origin. Cook et al. (2004a) utilized a fourteen chronology ring width data set used previously to model lowfrequency temperature variability for the past millennium (Esper et al., 2002). The data from these fourteen sites were split into northern (eight boreal sites, $55^{\circ}-70^{\circ} \mathrm{N}$ ), and southern (six temperate sites, $30^{\circ}-55^{\circ} \mathrm{N}$ ) groups. While the northern group, which broadly corresponds to the region considered most sensitive to divergence by Briffa et al. (1998a,b), shows a significant recent downturn, the southern group does not and is more consistent with recent warming trends. Cook et al. (2004a) and Briffa et al. (1998a) discovered less divergence in the more southern regions, with declines in common variance with temperature of $5-12 \%$ vs. over $30 \%$ for some northern regions. Considerably more such research is needed, however, before we can conclude unequivocally that the recently observed divergence phenomenon is unique over the past thousand years and is more pronounced in the northern hemisphere.

Under global climate change, future increases in the severity of extreme climatic events may be expected to impact forests in a wide variety of ways (IPCC, 2001b). In some areas, the projected warming poses a risk for much drier conditions in northern continental regions, potentially leading to large-scale impacts on forests either directly (Hogg and Hurdle, 1995), or in combination with drought-induced increases in fire (Flannigan et al., 1998). There is evidence that increased drought stress associated with recent climatic warming has already led to reduced tree growth in some high-latitude areas such as Alaska (Barber et al., 2000). Potentially, climate change may also lead to losses of boreal forest cover following disturbance in areas that become too dry for regeneration to occur (Hogg and Schwarz, 1997). Furthermore, climate change poses a risk of increasing forest damage from outbreaks of pests (Volney and Fleming, 2000), including both native and exotic species (Krcmar-Nozic et al., 2000). The concerns for large-scale impacts also extend to the tropics, where large areas of rain forests have been recently devastated by the combined impacts of drought, selective logging and fire (Siegert et al., 2001). In the northern hardwood forests of the eastern U.S. and Canada, 
thaw-freeze events in winter and early spring have also been implicated as a major cause of forest dieback episodes during the past century (Auclair et al., 1996), but such events are rarely considered in large-scale models.

Increasing evidence indicates that warmer and earlier springs lead to earlier snow melt and stronger evaporation in temperate continental semi-arid mountain forests in the northern hemisphere (Ye et al., 1999; Barnett et al., 2005; Xu et al., 2008), where the water supply in the early growing season is dominated by the melting of winter snow (Barnett et al., 2005, Adam et al., 2009). Earlier snow melt leads to faster and earlier runoff in spring (Barnett et al., 2005; Xu et al., 2008) and a possible reduction of water storage available for active tree growth.

Barber et al. (2000) investigated ring widths, density and isotopic records from closed canopy, productive upland white spruce stands in the interior boreal forest zone of Alaska. They concluded that temperature-induced drought stress was the cause of divergence at their sites, with the greatest declines in temperature sensitivity found in the faster-growing trees.

Lloyd and Fastie (2002) found that growth declines were widespread in an analysis of tree-ring records from eight alpine and latitudinal treeline sites in Alaska. After 1950, warmer temperatures were associated with decreased tree growth in all but the wettest region, the Alaska Range. Negative responses to temperature were found that were widespread across Alaska's boreal forests. Growth declines were more common at the warmer and drier locations, leading these authors to conclude that drought stress may have accompanied the increased warming of these forests in recent decades.

Davi et al. (2003) detected a decline in temperature sensitivity and tree growth after 1970 in ring width data from elevational treeline sites in the Wrangell mountain region of southeastern Alaska. This decline coincided with warming in the instrumental temperature data, and was attributed to probable drought stress for at least one of the sites studied.

Tree-ring analysis of aspen (Populus tremuloides Michx) in western Canada showed that during the period 1950-2000 these forests have undergone major oscillations in growth. These cycles were mainly driven by drought and insect defoliation, which caused reduced growth. Besides, the influence of thaw-freeze events in late winter or spring, as well as damage by fungal pathogens and wood-boring insects, which tend to increase in aspen stands following drought or defoliation events were other causal factors (Hogg et al., 2003).

Another study in northwest China found that temperate continental semi-arid forests on the Tianshan Mountains are suffering from prolonged growth limitation in recent years accompanying spring warming. This prolonged limitation of tree growth was attributed to the effects of soil water limitation in early spring caused by the rapid spring warming. Warming-induced prolonged drought stress contributed, to a large part, to the marked reduction of regional basal area increment (BAI) in recent years and a much slower growth rate in young trees (Wu et al., 2013).

A dendroclimatic study on eastern white cedar (Thuja occidentalis) at its northern limit in North America found that radial growth was limited by short growing seasons and by summer moisture availability in the marginal zone. Growth was also limited by an excess of water before or after the growing season in some part of the gradient, especially in poorly drained soils (Housset et al., 2014). 


\section{Climate change and the Pandora's Box}

At this stage it is still inconclusive to state whether global climate change will actually enhance or reduce forest growth. The highly divergent results of researchers do not yield any consistent pattern that could shed light on the response of the world's forested biomes to the changing climate. Despite recent scientific and technological advances, a high degree of uncertainty remains in predicting the direction of change in the potential productivity of the world's forests. This uncertainty arises from the complexity in ascertaining how the effects of positive and negative factors will eventually balance out in a given geographical area. While a low to moderate increase in the concentration of greenhouse gases like carbon dioxide coupled with an increase in temperature may augment tree growth however, an uncontrolled increase in these parameters may either have adverse impacts on tree physiology and forest growth or the growth enhancement may reach a point of saturation.

A study by Andreu-Hayles et al. (2011) analysed the response of boreal forests to anthropogenic climate change using tree-ring data from the Firth River site at treeline in northeastern Alaska, in a tundra-forest transition region where pronounced warming has already occurred. Both tree-ring width (TRW) and maximum latewood density (MXD) chronologies were developed in white spruce (Picea glauca), a dominant Arctic treeline species. While the MXD chronology maintained a significant positive relationship with summer mean temperatures throughout the 20th century, for the TRW chronology good agreement with summer temperatures was found only from 1901 to 1950 , whereas no significant relationships were found from 1951 to 2001, an indication of the divergence phenomenon. Forests where 'divergence' is detected may have reached a threshold beyond which tree growth is no longer positively influenced by summer temperature. This could be linked to the unusually rapid warming of the late 20th century due to recent anthropogenic change (ACIA, 2005, Trenberth et al., 2007), as well as potentially greater moisture stress due to an increase in evapotranspiration demand (Angert et al., 2005, Bunn and Goetz, 2006, Beck et al., 2011). However, wider and denser rings were more frequent during the 20th century, particularly after 1950, than in previous centuries. Their study concluded that there was indeed an increase in forest productivity at this forest-tundra transition zone, though TRW may be more influenced than MXD by changes in phenological patterns linked to ongoing warming (Menzel and Fabian, 1999) or variations in snowfall and timing of snowmelt (Vaganov et al., 1999).

With global climate change and its cascading impacts on the biosphere, the pandora's box is indeed open but hope stills lies at the bottom of the box with a scope to adapt to or mitigate the foreseen climatic calamities. A deeper understanding of forest climate sensitivity is crucial for their conservation and management. Forest management practices should focus on the adaptive capacity of forests in light of their imminent vulnerability to the ravages of climatic change. This would only be possible if we have a clear understanding of what we are heading towards, with respect to forest growth and productivity in the coming years, when the ill effects of anthropogenic disturbances to global ecology are likely to manifest in one form or the other. As existing records are updated and new ones developed, we will be able to derive more accurate and reliable inferences concerning the pertinent question of forest growth dynamics in relation to the changing climate. 


\section{REFERENCES}

[1] Abrams, M.D. (2003): Where has all the white oak gone? - Bioscience 53: 927-939.

[2] Abrams, M.D., Orwig, D.A. (1995): Structure, radial growth dynamics and recent climatic variations of a 320 year-old Pinus rigida rock outcrop community. - Oecologia 101: 353-360.

[3] ACIA. (2005): Arctic Climate Impact Assessment. - Cambridge University Press, Cambridge.

[4] Adam, J.C., Hamlet, A.F., Lettenmaier, D.P. (2009): Implications of global climate change for snowmelt hydrology in the twenty-first century. - Hydrological Processes 23: 962-972.

[5] Andreu-Hayles, L., D'Arrigo, R., Anchukaitis, K. J., Beck, P.S.A., Frank, D., Goetz, S. (2011): Varying boreal forest response to Arctic environmental change at the Firth River, Alaska. - Environ. Res. Lett. 6045503.

[6] Angert, A., Biraud, S., Bonfils, C., Henning, C.C., Buermann, W., Pinzon, J., Tucker, C.J., Fung, I. (2005): Drier summers cancel out the CO2 uptake enhancement induced by warmer springs. - Proc. Natl Acad. Sci. USA 102: 10823-10827.

[7] Auclair, A.N.D., Lill, J.T., Revenga, C. (1996): The role of climate variability and global warming in the dieback of northern hardwoods. - Water, Air and Soil Pollution 91 (3-4): 163-186.

[8] Badeau, V., Becker, M., Bert, D., Dupouey, J.L., Lebourgeois, F., Picard, J.F. (1996): Long-term growth trends of trees: ten years of dendrochronological studies in France. In: Spiecker, H., Mielikainen, K., Kohl, M., Skovsgaard, J.P. (eds.). Growth trends in European forests. - Springer-Verlag, Berlin, Heidelberg, New York. 167-182.

[9] Baker, T. (2004): Increasing biomass in Amazonian forest plots. - Philosophical Transactions of the Royal Society of London Series B: Biological Sciences 359: 353365.

[10] Barber, V., Juday, G., Finney, B. (2000): Reduced growth of Alaska white spruce in the twentieth century from temperature-induced drought stress. - Nature 405: 668-672.

[11] Barnett, T.P., Adam, J.C., Lettenmaier, D.P. (2005): Potential impacts of a warming climate on water availability in snow-dominated regions. - Nature 438: 303-309.

[12] Bazzaz, F.A. (1990): The response of natural ecosystems to the rising global CO2 levels. - Annu. Rev. Ecol. Syst. 21:167-196.

[13] Beck, P.S.A., $\quad$ Atzberger, C., Hogda, K.A., $\quad$ Johansen, B., Skidmore, A.K. (2006): Improved monitoring of vegetation dynamics at very high latitudes: a new method using MODIS NDVI. - Remote Sens. Environ. 100: 321-334.

[14] Borgaonkar, H.P., Somaru, R., Sikder, A.B. (2009): Assessment of tree-ring analysis of high-elevation Cedrus deodara D. Don from Western Himalaya (India) in relation to climate and glacier fluctuations. - Dendrochronologia 27: 59-69.

[15] Bradley, R.S., Jones, P.D. (eds.) (1992): Climate since A.D. 1500. - Routledge, London.

[16] Briffa, K., Schweingruber, F., Jones, P., Osborn, T. (1998a): Reduced sensitivity of recent tree growth to temperature at high northern latitudes. - Nature 391: 678-682.

[17] Briffa, K., Schweingruber, F., Jones, P., Osborn, T., Harris, I., Shiyatov, S., Vaganov, A., Grudd, H. (1998b): Trees tell of past climates: but are they speaking less clearly today? Philosophical Transactions of the Royal Society of London Series B: Biological Sciences 353: 65-73.

[18] Brown, M., Pinzon, J., Tucker, C. (2004): New vegetation index data set available to monitor global change. - EOS, Trans. AGU 85 (52): 565-569.

[19] Bruce, J., Hengeveld, H. (1985): Our changing Northern Climate. - Geos 14(1): 1-6.

[20] Bunn, A., Goetz, S. (2006): Trends in satellite-observed circumpolar photosynthetic activity from 1982 to 2003: the influence of seasonality, cover type, and vegetation density. - Earth Interactions 10: 1-19. 
[21] Cao, M., Woodward, F.I. (1998): Net primary and ecosystem production and carbon stocks of terrestrial ecosystems and their responses to climate change. - Global Change Biology 4(2): 185-198

[22] Chen, W., Chen, J., Cihlar, J. (2000): An integrated terrestrial carbon-budget model based on changes in disturbance, climate, and atmospheric chemistry. - Ecological Modelling 135: 55-79.

[23] Cook, E.R., Esper, J., D'Arrigo, R.D. (2004a): Extra-tropical Northern Hemisphere land temperature variability over the past 1000 years. - Quat. Sci. Rev. 23: 2063-2074.

[24] D'Arrigo, R., Kaufmann, R., Davi, N., Jacoby, G., Laskowski, C., Myneni, R., Cherubini, P. (2004a): Thresholds for warming-induced growth decline at elevational treeline in the Yukon Territory. - Glob. Biogeochem. Cycles 18. doi:10.1029/2004GBO02249.

[25] D'Arrigo, R., Wilson, R., Liepert, B., Cherubini, P. (2008): On the 'Divergence Problem' in Northern Forests: A review of the tree-ring evidence and possible causes. - Global and Planetary Change 60: 289-305.

[26] Davi, N., Jacoby, G., Wiles, G. (2003): Boreal temperature variability inferred from maximum latewood density and tree-ring width data, Wrangell Mountain region, Alaska. - Quat. Res. 60: 252-262.

[27] Esper, J., Cook, E.R., Schweingruber, F.H. (2002): Low-frequency in long tree-ring chronologies for reconstructing past temperature variability. - Science 295: 2250-2253.

[28] Flannigan, M.D., Bergeron, Y., Engelmark, O., Wotton, B.M. (1998): Future wildfire in circumboreal forests in relation to global warming. - Journal of Vegetation Science 9: 469-476.

[29] Fritts, H.C. (1976): Tree ring and climate. - Academic Press, London, UK.

[30] Fritts, H.C. (1987): Principles and practices of dendroecology. - In: Proceedings of the International Symposium on Ecological Aspects of Tree-Ring Analysis. - U.S. Department of Energy, Marymount College, Tarrytown, New York.

[31] Girardin, M. P. (2014): Heterogeneous influences of climatic changes on productivity of black spruce forests across Canada. - Tree Rings in Archaeology, Climatology and Ecology (TRACE 2014), Aviemore, Scotland.

[32] Hattenschwiler, S., Miglietta, F., Raschi, A., Korner, C. (1997): Thirty years of in situ tree growth under elevated $\mathrm{CO}$ 2: a model for future forest responses. - Global Change Biology 3: 464-471.

[33] Hogg, E.H., Brandt, J.P., Kochtubajda, B. (2003): Climate change impacts on growth and decline of northern forests. - XII World Forestry Congress, Quebec, Canada

[34] Hogg, E.H., Hurdle, P.A. (1995): The aspen parkland in western Canada: A dry-climate analogue for the future boreal forest? - Water, Air, and Soil Pollution 82: 391-400.

[35] Hogg, E.H., Schwarz, A.G. (1997): Regeneration of planted conifers across climatic moisture gradients on the Canadian prairies: implications for distribution and climate change. - Journal of Biogeography 24: 527-534.

[36] Housset, J., Girardin, M., Carcaillet, C., Bergeron, Y. (2014): Unexpected recent warming-induced growth decline in Thuja occidentalis at its northern limit in North America. - Tree Rings in Archaeology, Climatology and Ecology (TRACE 2014), Aviemore, Scotland.

[37] Hughes, M.K. (2002): Dendrochronology in climatology - the state of the art. Dendrochronologia 20: 95-116.

[38] Intergovernmental Panel on Climate Change (IPCC). (2001b): Climate change 2001: Impacts, adaptation and vulnerability. (eds.) McCarthy, J.J., Canziani, O.F., Leary, N.A., Dokken, D.J., White, K.S. - Cambridge University Press, UK.

[39] International Panel on Climate Change (IPCC). (2001): Climate Change: The Scientific Basis. Contribution of Working Group I to the Third Assessment Report of the Intergovernmental Panel on Climate Change. Houghton, J.T., Ding, Y., Griggs, D. J., Noguer, M., van der Linden, P.J., Dai, X., Maskell, K., Johnson, C.A. (eds.), Cambridge University Press, Cambridge, UK.

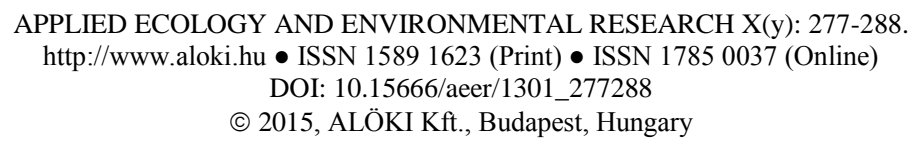


[40] International Panel on Climate Change (IPCC). (2007): Climate Change: The Scientific Basis: IPCC fourth assessment report, Working Group I. 996.

[41] Isebrands, J.G., McDonald, E.P., Kruger, E., Hendrey, G., Percy, K., Pregitzer, K., Sober, J., Karnosky, D.F. (2001): Growth responses of Populus tremuloides clones to interacting elevated carbon dioxide and tropospheric ozone. - Environ. Pollut. 115: 359-371.

[42] Karnosky, D.F., Skelly, J.M., Percy, K.E., Chappelka, A.H. (2007): Perspectives regarding 50 years of research on effects of tropospheric ozone air pollution on US forests. - Environ. Pollut. 147: 489-506.

[43] Korner, C. (2003): Carbon limitation in trees. - J. Ecol. 91: 4-17.

[44] Krcmar-Nozic, E., Wilson, B., Arthur, L. (2000): The potential impacts of exotic forest pests in North America: a synthesis of research. - Canadian Forest Service, Pacific Forestry Centre.

[45] LaMarche, V.C., Graybill, D.A., Fritts, H.C. (1984): Increasing atmospheric carbon dioxide: tree-ring evidence for growth enhancement in natural vegetation. - Science 225: 1019-1021.

[46] Laubhann, D., Sterba, H., Jan, R.G., de Vries, W. (2009): The impacts of atmospheric deposition and climate on forest growth in European monitoring plots: an individual tree growth model. - Forest Ecology and Management 258 (8): 1751-1761.

[47] Lewis, S.L. (2006): Tropical forests and the changing earth system. - Philosophical Transactions of the Royal Society of London Series B: Biological Sciences 361(1465): 195-210.

[48] Lloyd, A., Fastie, C. (2002): Spatial and temporal variability in the growth and climate response of treeline trees in Alaska. - Climate Change 58: 481-509.

[49] Lopatin, E., Kolstrom, T., Spiecker, H. (2008): Long term trends in radial growth of Siberian Spruce and Scots Pine in Komi Republic (north western Russia). - Boreal Environment Research 13: 539-552.

[50] Makinen, H., Nojd, P., Kahle, H.P., Neumann, U., Tveite, B., Mielikainen, K., Rohle, H., Spiecker, H. (2003): Large-scale climatic variability and radial increment variation of Picea abies (L.) Karst. in central and northern Europe. -Trees-Structure and Function 17: 173-184.

[51] Mann, M.E., Bradley, R.S., Hughes, M.K. (1999): Northern hemisphere temperatures during the past millennium: inferences, uncertainties, and limitations. - Geophys. Res. Lett. 26: 759-762.

[52] Menzel, A., Fabian, P. (1999): Growing season extended in Europe. - Nature 397: 659.

[53] Morgan, M.G., Pitelka, L.F., Sheviakova, E. (2001): Elicitation of expert judgments of climate change impacts on forest ecosystems. - Climatic Change 49 (3): 279-307.

[54] Myneni, R., Keeling, C., Tucker, C., Asrar, G., Nemani, R. (1997): Increased plant growth in the northern latitudes from 1981 to 1991. - Nature 386: 698-702.

[55] Nemani, R., Keeling, C., Hashimoto, H., Jolly, W., Piper, S., Tucker, C., Myneni, R., Running, S. (2003): Climate-driven increases in global net primary production from 1982. - Science 300: 1560-1563.

[56] Nicolussi, K., Bortenschlager, S., Korner, C.H. (1995): Increase in tree-ring width in subalpine Pinus cembra from the central Alps that may be CO2 related. - Trees 9: 181189.

[57] Phillips, O.L. (2009): Drought sensitivity of the Amazon rainforest. - Science 323: 13441347.

[58] Phillips, O.L., Gentry, A.H. (1994): Increasing turnover through time in tropical forests. Science 263: 954-958.

[59] Root, T.L., Price, J.T., Hall, K.R., Schneider, S.H., Rosenzweig, C., Pounds, J.A. (2003): Fingerprints of global warming on wild animals and plants. - Nature 421: 57-60.

[60] Rowe, J.S. (1967): Phytogeographic zonation: an ecological appreciation. - In: Taylor, R.L., Ludwig, R.A. (eds.), The evolution of Canada's flora. - University of Toronto press, Toronto.

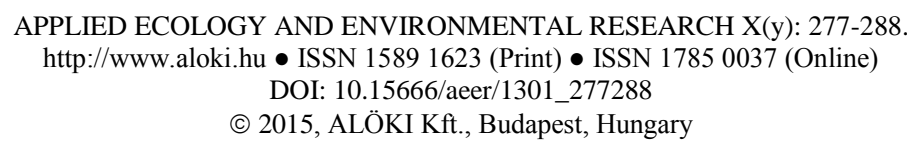


[61] Salzer, M.W., Hughes, M.K., Bunn, A.G., Kipfmueller, K.F. (2009): Recent unprecedented tree-ring growth in bristlecone pine at the highest elevations and possible causes. - Proceedings of the National Academy of Sciences of the United States of America 106 (48): 20348 -20353.

[62] Siegert, F., Ruecker, G., Hinrichs, A., Hoffmann, A.A. (2001): Increased damage from fires in logged forests during droughts caused by El Nino. - Nature 414 (6862): 437-440.

[63] Stokes, M.A., Smiley, T.L. (1968): An Introduction to Tree-Ring Dating. - University of Chicago Press, Chicago. 73.

[64] Stratton, L.E. (2007): Tree-ring records of late holocene climate change in the Hangay Mountains, Mongolia. - 20th Annual Keck Symposium, 54-60. http://keck.wooster.edu/publications.

[65] Swetnam, T.W., Thompson, M.A., Sutherland, E.K. (1985): Using dendrochronology to measure radial growth of defoliated trees. - USDA Forest Service Agricultural Handbook.

[66] Telewski, F.W., Swanson, R.T., Strain, B.R. (1999): Wood properties and ring width response to long-term atmospheric $\mathrm{CO} 2$ enrichment in the field-grown loblolly pine (Pinus taeda L.). - Plant, Cell and Environment 22: 213-219.

[67] Tissue, D.T., Thomas, R.B., Strain, B.R. (1997): Atmospheric CO2 enrichment increases growth and photosynthesis of Pinus taeda: A 4-year experiment in the field. - Plant, Cell and Environment 20: 1123-1134.

[68] Trenberth, K.E., Jones, P.D., Ambenje, P., Bojariu, R., Easterling, D., Klein Tank, A., Parker, D., Rahimzadeh, F., Renwick, J.A., Rusticucci, M., Soden, B., Zhai, P. (2007): Observations: Surface and Atmospheric Climate Change. In: Solomon, S., Qin, D., Manning, M., Chen, Z., Marquis, M., Averyt, K.B., Tignor, M., Miller, H.L. (eds.), Climate Change 2007: The Physical Science Basis. Contribution of Working Group I to the Fourth Assessment Report of the Intergovernmental Panel on Climate Change. Cambridge University Press, Cambridge, United Kingdom and New York, NY, USA.

[69] Vaganov, E.A., Hughes, M.K., Kirdyanov, A.V., $\quad$ Schweingruber, F.H., Silkin, P.P. (1999): Influence of snowfall and melt timing on tree growth in subarctic Eurasia. - Nature 400: 149-151.

[70] Volney, W.J.A., Fleming, R.A. (2000): Climate change and impacts of boreal forest insects. - Agriculture, Ecosystems and Environment 82 (1/3): 283-294.

[71] Wang, G.G., Sophan, C., Bauerle, W.L. (2006): Effect of natural atmospheric CO2 fertilization suggested by open-grown white spruce in a dry environment. - Global Change Biology 12: 601-610.

[72] Way, D.A., Oren, R. (2010): Differential responses to changes in growth temperature between trees from different functional groups and biomes: a review and synthesis of data. - Tree Physiol. 30: 669-688.

[73] White, A., Canell, M.G.R., Friend, A.D., Parry, M., Livermore, M. (1999): Climate change impacts on ecosystems and the terrestrial carbon sink: a new assessment. Global Environmental Change 9: S21-S30.

[74] Wu, X., Liu, H., Wang, Y., Deng, M. (2013): Prolonged limitation of tree growth due to warmer spring in semi-arid mountain forests of Tianshan, northwest China. Environmental Research Letters 8 024016. doi:10.1088/1748-9326/8/2/024016.

[75] Xu, C.C., Chen, Y.N., Li, W.H., Chen, Y.P., Ge, H.T. (2008): Potential impact of climate change on snow cover area in the Tarim River basin Environ. - Geol. 53: 1465-1474.

[76] Ye, B.S., Ding, Y.J., Kang, E.S., Li, G., Han, T.D. (1999): Response of the snowmelt and glacier runoff to the climate warming-up in the last 40 years in Xinjiang Autonomous Region, China. - Sci. China Ser. D 42: 44-51.

[77] Zhou, L., Tucker, C.J., Kaufmann, R.K., Slayback, D., Shabanov, N.V., Myneni, R.B. (2001): Variations in northern vegetation activity inferred from satellite data of vegetation index during 1981 to 1999. - Journal of Geophysical Research 106 (D17): 20069-20083. 